\title{
Impact of Corruption on Insurgency in the North-Eastern Region of Nigeria
}

\author{
Usman D. Umaru, Ph.D
}

\begin{abstract}
This study is on the Impact of Corruption on Boko Haram Insurgency in the North Eastern Region of Nigeria, specifically, Adamawa, Borno and Yobe States. The study adopted content and observational analysis. Documentary ideas as expressed in text books, journal articles, magazines, Internet and Newspapers was analysed and utilised. The documentary materials were complemented with the observation methodology of data collection. The period of the study is 2009 to 2015. In the course of the study, it was discovered that the failure of the Nigerian Military to defeat the Boko Haram Insurgents within the study period was due to corruption perpetuated by the office of the former National Security Adviser. In conclusion, it was clear without doubt that corruption had negatively impacted on the war against insurgency in the North Eastern Region of Nigeria and this was due to the sharing of the $\$ 2.1$ billion dollars and the questionable contracts awarded which were not executed by some companies and persons. The study therefore recommended that the Federal Government under President Muhammadu Buhari should continue with his war against corruption and ensure that all outstanding funds with the former National Security Adviser and his collaborators were retrieved.
\end{abstract}

\section{Introduction}

The North-Eastern Region of Nigeria is made up of Adamawa State, Bauchi State, Borno State, Gombe State, Taraba State and Yobe States, all within the Nigerian federation. These states were inhibited with almost all the tribes in Nigeria, who were either Moslems or Christians and were living peacefully with one another, with each going about his/her various business activities without any hindrance whatsoever. Their co-existence clearly describes what peace is all about i.e. a security friendly system that frees individual and groups of people from fear and danger of losing such inalienable human rights as life, liberty and property (Akpuru-Aja, 2007).

However in 2009, the peacefulness of this region was disrupted as a result of the emergence of an insurgent group known as Boko Haram, which means western education, is sinful, and are referred to as members of the Jama'atu Ahlis Sunna Lid-da'awati Wal-Jihad i.e. The group committed to the propagation of the Prophet's Teachings and Jihad. This group were against western education and anybody working for the government either as a civil servant, the army, police or paramilitary personnel. As such the insurgents started with attacking members of the Nigerian Police Force, the Army and other para-military personnel in Borno State. The insurgents later attacked and bombed the Force Headquarters and the United Nation's building at Abuja. Later the attacks spread to worship places like the mosques and churches. From there the insurgents started attacking towns and villages in Borno State, which later spread to Adamawa and Yobe States where they captured towns, villages and local government headquarters. The rate at which the insurgents were overwhelming the Nigerian military and the civilian population made Nigerians to doubt the capability of the Nigerian military to defeat the insurgents. These attacks, bombings and killing continued up to May, 2015. This study is therefore to assess the impact of corruption in the fight against the Boko Haram Insurgency in the North Eastern Region of Nigeria. The study will concentrate on the role of corruption on the activities of the insurgents in Adamawa, Borno and Yobe States. This is because these were the states that were mainly the target of the insurgents, despite their Guerrilla attacks in states like Bauchi, Kano, Abuja, Lokoja, Jos etc.

\section{Methodology}

The methodology adopted for this study is a content and observational analysis. Documentary ideas as expressed in text books, journal articles, magazines, Internet and Newspapers shall be analysed and utilised. These documentary materials shall be complemented with the observation methodology of data collection. The period of the study is 2009 to 2015 . This period was chosen because that was when the insurgents capture most of the local government areas in Borno and Yobe States and small ones in Adamawa State.

\section{Statement of the Problem}

The Nigerian military was a colonial creation, precisely British in orientation. Most of the earliest senior military officers were trained in Britain and India, as such were considered one of the best trained in Africa. In the area of international peace keeping, Nigerian Military performed excellently in many of the countries they were posted to by ECOWAS, African Union and the United Nations. The excellent performance of the Nigerian military in restoring peace in Liberia, Sierra Leon, Cote d' Ivoire and Guinea Bisssau were still 
fresh in the history of African conflicts. The same Nigerian military were confronted with an internal insurgency where many of them were maimed, killed and oth3rs missing in action. The military were unable to defend and protect the territorial integrity of the affected states. However, on the part of the military, there were rumoured complain of lack of weapons and other military hardware, despite the huge amount of money being budgeted by the government for the purchase of weapons and other military hardware to prosecute the war against the insurgents.

\section{Theoretical Framework}

This theoretical framework shall be discussed from the points of view of the origin and objective of the Boko Haran Insurgency and the theory that motivated the insurgency in the North Easter region, as put forward by Ossai (2014). These theories are the Islamization Agenda theory, Politically motivated theory, MEND kind of objective theory, population reduction theory, Nigeria world power threat theory and the Mao Zedong theory:

The Islamization Agenda theory is a theory that was associated with sects beginning with the etymological concept of the term "Boko Haram" which translate "western education is sinful" and whose objective seeks to establish a pure Islamic state ruled by the sharia law. This theory cannot be associated with this study because as at December 2012, nine northern states including Borno, Yobe and Adamawa states adopted sharia as a state religion and a part of its legal system. Following this theory was the Nigeria Membership of the Organization of Islamic Cooperation by the Nigerian State. Nigeria was expected to avoid anything that will make it to renounce its membership or fail to meet its responsibilities to the organisation, as failure to meet these responsibilities shall attract punishment in the form of terrorism. Again, this theory cannot hold sway, because prominent northern leaders were in support of the government of a Christian leader who ruled Nigeria for 13 years.

The next theory is the Political Motivated theory and the Oil Cartel theory which held that as a result of the past speeches of the northern politicians who threatened to make the country ungovernable if a northern politician is not elected president. This theory is not tenable because prominent northern politicians showed open support to the president. Another reason was the Oil Block Cartel theory which assets that most of the oil blocks owned by northern citizens will lost their licences in 2018/2019 hence they were desperate that one of their own should cease power prior to this time.

Another theory is the MEND kind of objective theory. The theory held that when the Federal Government of Nigeria resorted to dialoguing and "settling" the Niger Delta militants instead of fighting them to finish, it became clear to many northern politicians that the only way to draw the government attention to their youth is by creating a militant group in the north. This was further heightened by a military secret report instigated by President Umaru Musa Yar'adua, which indicted the late National Security Adviser, Azazi and some southern governors as sponsoring and diverting military artilleries to members of MEND has further created the possibility of this theory.

This theory is followed by the Population reduction theory which argued that Boko Haram was created by the Goodluck Jonathan government to reduce the population of the North in order to get competitive advantage in the next election. This theory is the least plausible of all the theories because Kano, Kaduna, Katsina were said to have fee air on the activities of the sect (But later, Kano and Kaduna had witness series of bomb attacks in Mosques and Churches).

The other theory is the World Power threat theory, which was an assertion by a reporter that a Wikileaks report once reported that the US embassy subversive activities was to contain Nigeria's rival potential to the US in the African continent, after Nigeria led ECOWAS forces without western support in intervened peace mission to Liberia, while at the same time engaging Sierra Leon in force peace combat with predominantly Nigerian troops. As such, Boko Haram was a CIA creation to undermine Nigeria's military power in Africa. This theory may not suffice because the same US is assisting Nigeria in its fight against insurgency.

The next theory is the Mao Zedong theory of Guerrilla War. Mao laid out the best blue print ever written for practical insurgent. Mao laid out the importance of winning the "hearts and minds" of the population as a crucial move because the population provides the support and cover for the insurgent. Mao laid out three phases of insurgency:

i) Political work: Working among the peasantry to win them over and build a base from which to operate. This was used by the Boko Haram insurgents as they took advantage of the poverty situation in the region to recruit poor and uneducated youths and also instigate their parents against constituted authority;

ii) Guerrilla Warfare: This is where the insurgents fight the state, but harassing actions or against communication and logistics. The objective is to weaken the enemy while consolidating one's own power. Again, Boko Haram successfully used this tactics, as they blow up all private telephone mars in their area of operation and carried out guerrilla attacks on markets, mosques, churches and motor parks, thus weakening the populace and the military. 
iii) Conventional war: Once the enemy is weak enough, the insurgents have enough control to fight largescale battles and take control of the ground. Again, the Boko Haram insurgents after the bombings and kidnappings started a full scale war by attacking and taking control of towns, villages and local government headquarters.

None of the earlier five theories clearly explain the objective of the Boko Haram Insurgency, while the World power threat theory created doubt, because of its possibility considering the weapons used by the insurgents, the USA should be exonerated, rather the search light should be beamed on big multi national oil companies and their supporting countries close to Nigeria. This is because of the oil deposits in the North Eastern Region, especially Borno State (Umaru,2015). However, the known objective of the Boko Haram Insurency in the North East was their desire to islamise the country, especially Northern Nigeria and establishes caliphates as was done in Gwoza Local Government Area of Borno State which was captured by the insurgents (Umaru, 2015). Mao Zedong's theory is apt because all the phases in the theory were clearly used by the Boko Haram insurgents in the North Eastern region.

\section{Conceptualizations}

Transparency International gave a vivid and descriptive concept of corruption in a broader sense when it refers to corruption as the misuse of entrusted power by heritage, education, marriage, election, appointment or whatever else for private gain. The broader concept of corruption not only covers the politician and public servants, but also the chief executive officer of a company, the notary public, the team leader at work place, the administrator or admissions office to a school or tertiary institution or hospital, the coach of a soccer, etc. However, major corruption comes close whenever major events involving large sums of money, often in disaster situations that are chaotic like insurgency and civil wars (TI, 2016). Apart from the above concept of corruption in general, of specific relevant to this study is the Bureaucratic corruption. Bureaucratic corruption is the taking advantage of and the manipulation of existing rules, regulations, procedures, instructions, opportunities, positions, guidelines and directives provided by an organization for personal gains at the expense of the organizational objectives (Umaru, 2013). Bureaucratic corruption is the use of one's position as a public official to misuse government resources, authority and responsibility for one's or group advantage.

Insurgency therefore is the insurrection against an existing government, usually one's own, by a group not recognised as having the status of a belligerent. The Boko Haram insurgency is an insurrection against the Nigerian state by some citizens of Nigeria. Terrorism on the other hand is a sub-set of insurgency. It has been defined by Sampson and Onuoha (2011) as cited by Bina (2016), as the premeditated use of or threat use of violence by an individual or group to cause fear, destruction or death, especially against unarmed targets, property or infrastructure in a state, intended to compel those in authority to respond to the demands or expectations of the individual or group behind such violent acts. The contemporary terrorism in Nigeria, especially in the north eastern region, is being perpetuated by the Boko Haram insurgents.

\section{Literature Review}

The Transparency International definition of corruption as the mis-use of entrusted power by appointment readily comes into play in the case of corruption that had wrecked havoc on the fight against insurgency in the north eastern region. This is because some politicians, senior military and civilian officials of the government in Nigeria were entrusted with large sums of fund meant for the procurement of arms, ammunition and other military hardware, payment of duty allowances to soldiers serving in the war zones etc were allegedly not used for the purpose intended.

The Nigerian state is far above the Boko Haram insurgents in terms of intelligence gathering, air and sea power and military manpower, but with all thee at the disposal of Nigeria, the insurgents seems to be growing stronger, killing, destroying, burning, marauding and kidnapping, despite the huge amount of funds voted for defence in order to prosecute the war against insurgency. See Table 1 below:

Table 1 Budget Numbers for the Federal Ministry of Defence from 2003 - 2014

\begin{tabular}{|l|l|l|l|l|}
\hline S/No & Year & Recurrent $(\boldsymbol{N})$ & Capital $(\boldsymbol{N})$ & Total $(\boldsymbol{N})$ \\
\hline 1 & 2003 & $54,575,272,206$ & $8,003,602,245$ & $62,578,874,451$ \\
\hline 2 & 2004 & $65,400,230,288$ & $10,657,110,640$ & $76,057,340,928$ \\
\hline 3 & 2005 & $90,333,808,875$ & $21,535,160,001$ & $111,868,968,876$ \\
\hline 4 & 2006 & $85,752,943,575$ & $15,699,001,188$ & $101,451,944,753$ \\
\hline 5 & 2007 & $103,095,201,633$ & $19,219,305,774$ & $122,314,507,407$ \\
\hline 6 & 2008 & $154,051,142,427$, & $37,464,075,290$ & $191,515,217,717$ \\
\hline 7 & $* 2009$ & & & $223,021,861,244$ \\
\hline 8 & 2010 & $217,340,355,870$ & $74,378,713,315$ & $291,719,069,185$ \\
\hline 9 & 2011 & $309,783,758,334$ & $35,253,289,044$ & $345,037,047,378$ \\
\hline 10 & 2012 & $314,299,342,619$ & $45,436,143,373$ & $359,735,485,992$ \\
\hline 11 & 2013 & $304,913,982,304$ & $59,251,900,000$ & $364,415,145,885$ \\
\hline 12 & 2014 & $314,347,339,871$ & $35,360,000,000$ & $349,707,339,871$ \\
\hline
\end{tabular}


Source: Olumhense, (2014)

*The archives of the National Assembly do not show a Appropriation Act, but the Budget the Budget office provides detailed Defence Appropriation totalling N223,021,861,244.

Table 1 above shows that a total of over N2.6 trillion have been spent on Defence from 2003 to 2014. But it should be noted that in some of the years covered, there were supplementary appropriations that have not been included. The office of the National Security Adviser played a great role in dealing with the insurgency in Nigeria; as such its budget is of interest. In 2006, the National Security Adviser received a budget of N15.5 billion, i.e. N12,316,686,404 for recurrent expenditure and N183,313,596 for capital expenditure. In 2010, a total of $\mathrm{N} 185,570,007,818$ i.e. N107,147,611,048 from the regular budget and N78,422,396,770 from a supplementary vote. In 2011, the sum of N109.8 billion was budgeted. In 2012, the sum of N115.5 billion was budgeted and in 2014 the sum of N117.7 billion were budgeted with the recurrent expenditure having the sum of N66,625,072,907 and capital expenditure having the sum of N51,100,000,000.00. These defence spending calls for proper utilization because they are sufficient to meet the demand for better weaponry and equipment and also to motivate the armed forces and other security agencies involved in the war against insurgency (Olumhense, 2014). But that was not the case, because those entrusted with the management of the budgeted funds were alleged to have mismanaged them.

\section{Change of Leadership in Nigeria}

When President Muhammadu Buhari took over the mantle of leadership from the former President, Goodluck Jonathan in 2015, it was discovered that Nigeria's foreign reserve was depleted, Excess Crude Account was expended and official looting was fully entrenched. In fact, Nigerian economy quivered, while elites occupying top government positions pilfered. This was the case of Nigeria under former President Goodluck Jonathan (Jimoh, 2016). This scenario made President Muhammadu Buhari to insist that things must change. When he said:

"All fraud must stop. If they don't believe us, they should go and see those we caught red-handed with public funds. This exercise will continue as long as this leadership is here. Whoever takes anything that does not belong to him or that he's not entitle to, it'll be documented and the person will be taken to court. This is the only way I think we can bail ourselves out," (Jimoh, 2016, page 14).

Thus, the Buhari Administration has successfully retrieved from corrupt officials of the past government cash amounting to N78,325,354,631.82; $\$ 185,119,584.61 ; 3,508,355.46$ pounds; between May $29^{\text {th }}, 2015$ to May $25^{\text {th }}, 2016$. Other recoveries under interim forfeiture, which were a combination of cash and assets, during the same period, were N126, 563,481,095.43; $\$ 9,090,243,920.15 ; 2,484,447.55$ pounds. In addition, 239 non cash recoveries were made during the one year period including farmlands, plots of land, uncompleted buildings, completed buildings, vehicles and maritime vessels (Jimoh, 2016). This readily brings to mind the statement of late Professor Chinua Achebe as cited by Karl (2000), in his book "This House has fallen: Nigeria in Crisis."

Nigerians are corrupt because the system under which they live today makes corruption easy and profitable; they will cease to be corrupt when corruption is made difficult and inconvenient ------ The trouble with Nigeria is simply and squarely a failure of leadership. There is nothing basically wrong with the Nigerian character. There is nothing wrong with the Nigerian land or climate or water or air or anything else. The Nigerian problem is the unwillingness or inability of its leaders to rise to the responsibility, to the challenge of personal example which are the hallmarks of true leadership ....... I am saying that Nigeria can change today if she discovers leaders who have the will, the ability and the vision (Karl, 2000, page 144).

Based on Professor Chinua Achebe's prophetic statements, is President Buhari the leader who have the will, the ability and the vision to rescue Nigerian from the shackles of corruption?

\section{Impact of Corruption on Arms Procurement}

Buhari's Administration unravelled the biggest scam in the history of Nigeria, when it decided to probe spending of funds meant for the procurement of arms and ammunition under the immediate past regime of former President Goodluck Jonathan. It was discovered that a former National Security Adviser (Col. Sambo Dasuki, rtd.) and others allegedly laundered and diverted $\$ 2.1$ billion dollars (over N550 billion) arms funds. The former National Security Adviser shared the arms fund as follows: 
Impact Of Corruption On Insurgency In The North-Eastern Region Of Nigeria

Table 2: Sharing of Arms and Ammunition Funds by NSA

\begin{tabular}{|l|l|l|l|l|}
\hline S/No & Name & Amount & Purpose & Remarks \\
\hline 1 & Attahiru Bafarawa & N4.6 billion & Spiritual purposes & Arrested by the EFCC \\
\hline 2 & Chief Raymond Dokpesi & N2.1 billion & Publicity \& Media & Arrested by the EFCC \\
\hline 3 & Alh. Aminu Babakusa & N2.2 billion & Shared to politicians & Promise to refund part. \\
\hline 4 & Waripamowei Dudafa & N10 billion & Shared to PDP delegates & - \\
\hline 5 & Chief Olisa Metu & N1.4 billion & Shared to politicians & Arrested by the EFCC \\
\hline 6 & Bala James Ngillari & N450 million & - & Arrested by the EFCC \\
\hline 7 & Mrs. Esther Nenadi Usman & N2.5 billion & Shared to party officials & Arrested by EFCC \\
\hline 8 & Air Marshal Adesola Amosu $(\mathrm{rtd})$ & Returned N2.3 billion & - & Returned N2.3 billion \\
\hline 9 & Air Chief Marshal Alex Badeh $(\mathrm{rtd})$ & $\$ 930,500$ and $\$ 690.00$ & Questionable contracts & Arrested by the EFCC \\
\hline 10 & Femi Fani-Kayode & N840 million & Campaign publicity & Arrested by the EFCC \\
\hline 11 & Chief OluFalae & N100 million & Received from Mrs. Usman & - \\
\hline 12 & Rashidi Ladoja & N100 million & Received from Mrs. Usman & - \\
\hline 13. & Prof. Rufai Alkali & N320 million & Support Group & - \\
\hline 14 & Bashir Yuguda & $\begin{array}{l}\text { N1.5 billion, N1.2 } \\
\text { billion, N775 million }\end{array}$ & Suspicious payments. & \\
\hline
\end{tabular}

Source: Adapted from Jimoh, 2016.

Table 2 showed how the amount meant for arms and ammunition procurements were shared by the former National Security Adviser. Furthermore, as a result of the questionable contracts awarded by the former National Security Adviser, some companies and persons were found guilty of some infractions such as : breach of contract terms; non-execution of contracts; haphazard or partial completion of contracts; collection of funds for unexecuted contracts, diversion of funds for political purposes; and sheer mismanagement of contract funds. As such, these companies and persons were to make funds to the Federal Government of President Muhammadu Buhari as follows:

Table 3: Amounts to be refunded to the Fed. Govt. by Companies and Persons

\begin{tabular}{|l|l|l|}
\hline S/No. & Companies and Persons & Amount to be Refunded \\
\hline 1 & Acacia Holding Limited & N600 million \& N650 million \\
\hline 2 & Reliance Referral Hospitals Limited & N750 million \\
\hline 3 & Societe d'Equip Internationaux & $\$ 148$ million, $.4,148$ million \\
\hline 4 & Arailac Global Limited & N100 million \\
\hline 5 & Stellavera Development Company & N250 million \\
\hline 6 & African Cable Television Limited & N350 million \\
\hline 7 & DAAR Investment Holding & N2,120,000.00 \\
\hline 8 & Bello Matawalle & N300 million \\
\hline 9 & Bello Fadile & N100 million \\
\hline 10 & Former National Security Adviser & $\$ 47$ million \\
\hline 11 & Shuaibu Salisu & $\$ 47$ million \\
\hline
\end{tabular}

Source: Adapted from Jimoh, 2016.

Table 3 above, contains names of companies and persons involved in questionable contracts and were asked to make refunds to the Federal Government. All the amounts quoted in table 2 and 3 were originally meant for arms and ammunition procurement by the office of the former National Security Adviser but were diverted and used for other purposes, which resulted in the following consequences to the war against insurgency in the north eastern region:

\section{Impact of Corruption on war against insurgency}

It was the failure of the office of the former National Security Adviser to procure the required military arms and ammunitions that made it impossible for the Nigerian military to effectively protect the citizens of the areas affected by the insurgency such that in Benisheikh, Boko Haram killed 160 people; 23 people were killed in a village in Kukawa local government area Idris and Ibrahim, 2013). 228 people were also killed by Boko Haram in Baga town and about 4,000 houses burnt (Ibrahim and Bashir, 2013); 55 people were further killed by Boko Haram in Bama town (Ibrahim and Sawab, 2013); in Konduga town, 57 civilians were killed; Izge town was attacked by Boko Haram and 106 civilians were killed (Idris and Ibrahim, 2014). All these killings happened in Borno State. In Yobe State, Boko Haram insurgents killed 62 students of College of Agriculture in Gujba town (Yakubu, 2013); 30 students of the Government secondary school in Mamudo were also killed by the insurgents (Hamza and Matazu, 2013); 59 students of Federal Government College, Buni Yadi in Gujba Local Government Area were killed over-night by the Boko Haram insurgents in their respective hostels (Matazu and Wakili, 2014). In Adamawa State, precisely at Shuwa and Michika towns, dozens of people were killed (Anwar, 2014);

Apart from the Killings in these three states of the north eastern region, the Boko Haram insurgents moved to other parts of Nigeria: In Abuja, the Federal Capital of Nigeria, 21 persons were killed and 25 others 
injured, apart from the destruction of vehicles, at one of the busiest shopping malls (Ogechi and Azu, 2014). In Bauchi Metropolis, Boko Haram members struck at a popular hotel and killed 13 persons in addition to injuring 34 others (Orude, 2014). The residents of Sabon Gari area in the Kano Metropolis (an area inhibited by nonindigenes) were bombed by the Boko Haram Sect and about 45 people were killed (Adeyemi, 2013). Also the Kano Central Mosque attacked,where multiple bombs exploded during Juma'at prayers and about 100 worshippers were killed (Mudashir, 2013).

\section{Impact of Corruption on captured Territories}

As a result of the inability of the Military to properly defend Adamawa, Borno and Yobe States against the marauding Boko Haram insurgents, the insurgents were able to capture 21 local government areas out of 27 local government areas in Borno State. In Yobe State, the Sect captured Buni Yadi, Buni Gari, Bularafa, Gulani, Bumsa, Ngirbuwa, Sirdi, Muktum, Goniri, Katarko and Gubja (Matazu, 2014). In Adamawa State, Mubi, Michika, Madagali were also captured by the Boko Haram Sect. But later, the Military and the Local Hunters recaptured Mubi town. (Anwar, 2014).

\section{Impact of Corruption on Military Discipline}

The Nigerian Army is a highly disciplined organization. However, the discipline within the members of the Nigerian army fighting the insurgents in Borno State broke down to the extent that on the $14^{\text {th }}$ of May, 2014, Eighteen (18) soldiers of 7 Division of the Nigerian Army in Maiduguri were Court Martialed and sentenced accordingly for protesting the insensitivity to their safety in the operations against Boko Haram insurgency. Twelve of them were sentenced to death by firing squad an d six others would serve varying prison terms according to their degree of involvement in the mutiny. The Court Martial found them guilty for disobeying superior orders in addition to insubordination (Yakubu, 2014). Another set of 54 members of the armed forces attached to the 7 Division were again Court Marshal on the $17^{\text {th }}$ of December 2014. They were found guilty for conspiring to commit mutiny against the authority of the 7 Division on August $4^{\text {th }} 2014$ by refusing to join the 111 (one hundred and eleven) Special Forces Battalion Troops to recapture Delwa, Bulabulin and Damboa in Borno State from the Boko Haram (Premium Times, 2014).

\section{Conclusion}

It is clear without doubt that corruption had negatively impacted on the war against insurgency in the North Eastern Region of Nigeria, as a result of the failure of the Office of the former National Security Adviser (Col. Sambo Dasuki rtd.). This failure manifested in the $\$ 2.1$ billion dollars allegedly laundered and diverted which consequently led to the abilities of the insurgents to over-run the Nigerian Military and thus capturing local governments in Borno, Yobe and Adamawa States.

\section{Recommendations}

The federal government under the leadership of President Muhammadu Buhari should ensure that it recovers all outstanding amounts with the former National Security Adviser and his collaborators. Also, the procurement of arms and ammunition and other military hard-wares should follow due process and carried out only by the appropriate organ of the federal government to prevent abuse. Furthermore, the welfare, safety and payment of duty allowances to members of the Nigerian army fighting the insurgent should be given top priority.

\section{References}

[1]. Adeyemi, I. (2013). Kano Death Toll hits 45. Lagos. The National Newspaper, July $31^{\text {st }}$, pages 1-4.

[2]. Akpuru-Aja, A. (2007). Basic Concepts, Issues and Strategies of Peace and Conflict Resolution. Enugu, Keny and Brothers Ent. (Nigeria).

[3]. Anwar, K.R. (2014). Boko Haram Sacks Army Bas, Madagali Town. Abuja, Sunday Trust Newspaper, August $24^{\text {th }}$, page 1.

[4]. Bina, F.R. (2016). Effect of Insecurity on the Livelihood of Communities of Maiduguri Metropolis, Borno State. Unpublished M.Sc. Seminar Paper, Department of Public Administration, University of Maiduguri.

[5]. Hamza, I. and Matazu, H.K. (2013). JTF Detains Borno ANPP Chairman and Sect Kills 30 Students in Yobe. Abuja, Sunday Trust Newspaper, July $7^{\text {th }}$, pages $1-4$

[6]. Ibrahim, Y. and Bashir, M. (2013). Baga Massacre: I Counted 228 Graves, 4,000 Destroyed Houses. Abuja, Sunday Trust Newspaper, April $18^{\text {th }}$, pages $1-3$.

[7]. Ibrahim, Y. and Sawab, I. (2013). 55 Dead as Gunmen Attack Borno town. Abuja, Daily Trust

[8]. Newspaper, May $8^{\text {th }}$, page 1.

[9]. Idris, H. and Ibrahim, Y. (2013). Boko Haram Kills 43 Borno Villagers. Abuja, Daily Trust Newspaper, July $29^{\text {th }}$, Page 1.

[10]. Idris, H. and Ibrahim, Y. (2014). 106 Killed in Fresh Borno Attack. Daily Trust Newspaper, February $17^{\text {th }}$, page 1.

[11]. Jimoh, A.(2016). Grand Theft Nationale: How Elites Stole Nigeria Dry. Abuja, Daily Trust, Saturday Newspaper, pages 14-15.

[12]. Karl, M. (2000). This House has fallen: Nigeria in crisis. London, Penguin Group.

[13]. Matazu, H.K. and Wakili, I. (2014). Yobe College Death Toll Hits 59. Abuja, Daily Trust Newspaper, Februyary $26^{\text {th }}$, page 1.

[14]. Matazu, K.M. (2014). Boko Haram Sacks Towns in Yobe State. Abuja Daily Trust Newspaper, July $30^{\text {th }}$ page 1.

[15]. Mudashir, I. (2014). Scores Killed in Kano Central Mosque Blast. Abuja, Weekly Trust Newspaper, November $29^{\text {th }}$, page 5. 
[16]. Ogechi, R.C. and Azu, J.C. (2014). Abuja Mall Blast Kills 21. Abuja, Daily Trust Newspaper, June $26^{\text {th }}$, Page 1.

[17]. Olumhense, S.S. (2014). Let Us Probe Nigeria's Defence Spending. Abuja, Sunday Trust, September $14^{\text {th }}$, page 64 .

[18]. Orude, P. (2014). 13 Killed, 34 Injured in Blast, Shootings in Hote. Lagos, Sunday Sun Newspaper, June 29 ${ }^{\text {th }}$, page

[19]. Ossai, T.O. (2014). Six Theories of the Boko Haram Insurgency. Retrieved on $6^{\text {th }}$ August, 2016, from www.saharareporters.com

[20]. Premium Times (2014). 54 Soldiers to Die for Mutiny.Abuja, Daily Trust Newspaper, December $18^{\text {th }}$ page 14.

[21]. Umaru, U.D. (2015). Insecurity and National Integration: The Case of Jama'atu Ahlis-Sunnah Lid-Da'awati Wal-Jihad (Boko Haram) Insurgency in Nigeria. Kaduna, Sahel Analyst, Journal of Management Sciences, Faculty of Management Sciences, University of Maiduguri, Borno State, Nigeria. Pages 83-102.

[22]. What is Corruption? Retrieved on $7^{\text {th }}$ August, 2016, from www.transparency.org

[23]. What is Insurgency? Retrieved on $7^{\text {th }}$ August, 2016, from www.dictionary.org

[24]. Yakubu, D. (2013). Nigeria at 53. Abuja, The Politico Magazine, October $21^{\text {st }}$, pages 21-28.

[25]. Yakubu, D. (2014). The Maiduguri 12 Must Not Die. Abuja, The Politico Magazine, October $6^{\text {th }}$ pages 13-17. 